\title{
Mommy, why can't I see clearly?
}

Nurulhuda Md Amin ${ }^{1,2}$, Safiyah Jameelah Mohd Yusof ${ }^{1}$, Nor Fadzillah Abd Jalil ${ }^{1}$, Raja Norliza Raja Omar ${ }^{1}$, Mushawiahti Mustapha ${ }^{2}$

${ }^{1}$ Ophthalmology Department, Hospital Melaka, Melaka, Malaysia; ${ }^{2}$ Ophthalmology Department, University Kebangsaan Malaysia Medical Centre, Kuala Lumpur, Malaysia

\section{Abstract}

Ectopia lentis or crystalline lens subluxation is one of the major criteria to diagnose Marfan syndrome. It may vary from mild lens subluxation to lens dislocation. Herewith is a case report of a 4-year-old autistic boy who had never been diagnosed with Marfan syndrome. He presented to the clinic after his parents noticed he had difficulty focusing on near objects. His bilateral best-corrected visual acuity was $6 / 60$. On examination, there was bilateral lens subluxation superotemporally and lens equator blocking his visual axis. He was sent to the paediatric team and further Marfan workout showed dilated aortic root. He was then diagnosed with Marfan syndrome. He underwent bilateral lens aspiration, anterior vitrectomy, and iris-claw lens implantation. His postoperative bilateral visual acuity on day 1 was $6 / 30$ and his best-corrected visual acuity 3 months after surgery was $6 / 9$ for both eyes. In conclusion, ophthalmologists play an important role in diagnosing and managing Marfan syndrome. Early diagnosis is important to help preserve vision and improve quality of life.

Keywords: ectopia lentis, iris-claw intraocular lens, Marfan syndrome

Correspondence: Dr. Nurulhuda Md Amin, MBBS, Ophthalmology Department, Hospital Melaka, Jalan Mufti Haji Khalil, 75400, Melaka, Malaysia.

E-mail: nurulhuda86dr@gmail.com 


\section{Emak, mengapa saya tidak dapat melihat dengan jelas?}

\section{Abstrak}

Ectopia lentis atau subluksasi kanta adalah salah satu kriteria utama untuk diagnosa sindrom Marfan. Spektrum perubahan pada kanta termasuk subluksasi kanta yang ringan sehingga berlakunya dislokasi kanta. Berikut adalah laporan kes seorang kanak-kanak lelaki autisme berusia 4 tahun yang tidak pernah diketahui mengidap sindrom Marfan. Dia hadir ke klinik setelah ibu bapanya menyedari bahawa dia sukar menumpukan perhatian pada objek berhampiran. Kedua- dua matanya mempunyai ketajaman penglihatan yang terbaik 6/60. Pemeriksaan klinikal menunjukkan subluksasi kanta ke arah superotemporal dan ekuator kanta menghalang paksi penglihatan pada kedua-dua belah matanya. Dia dirujuk kepada pakar pediatrik dan penyiasatan selanjutnya menunjukkan dilatasi pangkal aorta. Berdasarkan bukti ini, diagnosa sindrom Marfan telah dibuat. Pembedahan aspirasi kanta, vitrekomi anterior, dan implantasi kanta iris telah dijalankan ke atas kedua-dua belah mata. Ketajaman penglihatan kedua-dua belah mata mula pulih kepada 6/30 pada hari pertama pasca pembedahan dan terus meningkat kepada 6/9 selepas 3 bulan pasca pembedahan. Kesimpulannya, pakar oftalmologi memainkan peranan penting dalam pengesanan dan perawatan sindrom Marfan. Diagnosis awal adalah penting untuk membantu memelihara penglihatan dan meningkatkan kualiti hidup.

Kata kunci: ectopia lentis, kanta intraokular iris, sindrom Marfan

\section{Introduction}

Marfan syndrome (MS) is an autosomal dominant genetic connective tissue disorder due to mutations in the fibrillin-1 gene. ${ }^{1}$ Fibrillin defects lead to zonular defects, causing subluxated or dislocated lens. Other ocular features of MS are increased axial length, astigmatism, flat cornea, glaucoma, microspherophakia, peripheral retinal degenerations, and retinal detachment. ${ }^{2}$

Early surgical intervention is highly recommended in paediatric patients when there is lens subluxation or dislocation causing visual impairment to ensure early visual rehabilitation and prevent amblyopia. ${ }^{3}$ 


\section{Case report}

A 4-year old autistic boy presented to us after his parents noticed he had difficulty focusing on near objects. At presentation, both eyes had subluxated lens causing significant visual impairment. He was born full term with normal antenatal history. There was no history of squint or headtilt. We report this case due to its clinical significance, given this has been the youngest patient with undiagnosed MS reported to date in Malaysia. Early surgical intervention was done to prevent amblyopia. This is also to ensure he has clear vision to undergo Early Intervention Programme for Autism Spectrum Disorder. ${ }^{4}$

On examination, best-corrected visual acuity (BCVA) in both eyes was 6/60. Both lenses were found to be subluxated superotemporally and the equators were bisecting the visual axis (Fig. 1). The cornea, anterior chamber (AC), intraocular pressure, and fundus were normal. The right eye axial length was $29.61 \mathrm{~mm}$ and the

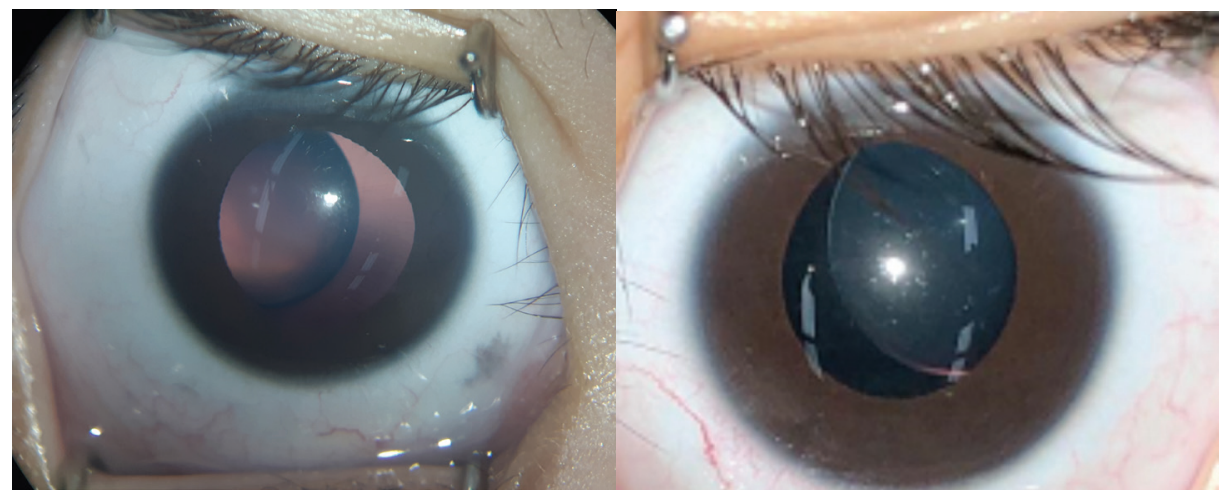

Fig. 1. Right eye (left) and left eye (right) showing both lens subluxated superotemporally.

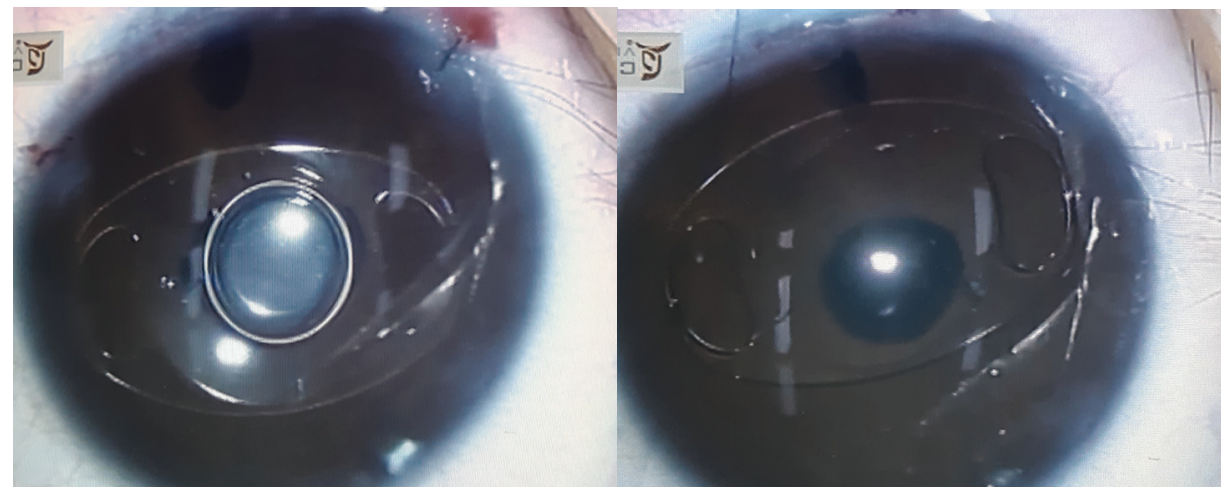

Fig. 2. Right eye (left) and left eye (right) after iris-claw IOL implantation. 
left eye axial length was $29.02 \mathrm{~mm}$. Taken together, the findings upon examination arose suspicion of MS. He was referred to a paediatrician for further MS workout. The paediatric team found the aortic root was significant dilated and the diagnosis of MS was confirmed.

He underwent bilateral lens aspiration, anterior vitrectomy, and iris-claw AC intraocular lens (IOL) implantation under general anaesthesia (Fig. 2). The surgical technique was modified to accomodate the subluxated lens. Capsular hooks were used to stabilise the lens centrally for the surgery and an iris-claw Artisan OPHTEC IOL (Groningen, Netherlands) (Table 1) was inserted for visual rehabilitation.

The surgical steps were as follows. Two paracenteses were made at the 2 and 4 o'clock position. The AC was filled with viscoelastic. A scleral tunnel was made superiorly. Continuous curvilinear capsulotomy was performed, and two capsular hooks were used to centralise the lens via the paracenteses. The lens was noted to be microspherophakic. Lens aspiration was done by automated irrigation and aspiration. This was followed by capsular removal and automated anterior vitrectomy. The remaining capsule was removed, as positioning the IOL in this case was not considered safe. An adult Artisan aphakia IOL was used given that the patient's white-to-white diameter was $12 \mathrm{~mm}$. IOL power was $+6.0 \mathrm{D}$ and $+7.0 \mathrm{D}$ for the right and left eye, respectively. The IOL was implanted after the pupil was pharmacologically miosed and the haptics were enclaved at the 3 and 9 o'clock position. An enclavation needle was used to enclave the haptic via a newly made paracentesis at 11 o'clock for the temporal haptic and via the pre-existing paracentesis at 2 o'clock for the nasal haptic. Peripheral iridectomy was made at 12 o'clock. The scleral tunnel was sutured with nylon 10-0 after viscoelastic removal. Intracameral cefuroxime (1 mg) was given, followed by subconjunctival dexamethasone at the end of the procedure. A similar procedure was done for the left eye. Topical Maxitrol by Alcon (Puurs, Belgium) every 2 hours was started 4 hours after surgery and was gradually tapered down over 2 months. The patient was discharged well 1 day after

Table 1. Dimensions of the Artisan aphakia IOL model 205.

\begin{tabular}{|l|l|l|}
\hline & Optic & $5.0 \mathrm{~mm}$, biconvex \\
\cline { 2 - 3 } & Body & $5.4 \mathrm{~mm}$ \\
\cline { 2 - 3 } & & \\
\cline { 2 - 3 } & Overall diameter & $8.5 \mathrm{~mm}$ \\
\end{tabular}


Table 2. Pre- and postoperative BCVA

\begin{tabular}{|l|l|l|}
\hline & Right eye & Left eye \\
\hline Preoperative BCVA & $6 / 60$ & $6 / 60$ \\
\hline $\begin{array}{l}\text { Preoperative } \\
\text { refraction }\end{array}$ & +5.00 & +6.00 \\
\hline Postoperative BCVA & $6 / 9$ & $6 / 9$ \\
\hline $\begin{array}{l}\text { Postoperative } \\
\text { refraction }\end{array}$ & $+0.50 /-1.25 \times 75$ & $+1.50 /-1.75 \times 95$ \\
\hline
\end{tabular}

BCVA: best-corrected visual acuity

the surgery.

One month post-surgery, examination under anaesthesia revealed a significant amount of astigmatism, therefore all sutures were removed. Eventually, the patient had good postoperative visual acuity and his BCVA and refraction pre- and post-surgery are shown in Table 2 . There were no postoperative complications.

\section{Discussion}

Almost 50\% of patients are diagnosed with Marfan syndrome primarily as part of the evaluation for ophthalmic complaints. ${ }^{5}$ Ectopia lentis is the most predominant ocular complication of MS. ${ }^{6}$ It is also one of the major criteria in diagnosing MS. ${ }^{7}$ Subluxation is usually toward the superotemporal direction, but the lens may also dislocate anteriorly, causing pupillary block glaucoma, as well as posteriorly into the vitreous.

Lens extraction with IOL implantation is the best choice for early visual rehabilitation, especially among the paediatric population. Romano et al. suggested early surgical intervention in children with subluxated lens, as $50 \%$ of their patients developed functional amblyopia despite good conservative management. ${ }^{3}$ They noticed amblyopia was worse when the lens was covering the visual axis and the lens edge was $1.3 \mathrm{~mm}$ from the centre of the pupil (range of 0.3 to $2.3 \mathrm{~mm}$ ) or bisecting the visual axis. Kanigowska et al. reported that $90 \%$ of their patients had marked improvement in vision after lensectomy and IOL implantation. ${ }^{8}$

Anterior chamber IOLs, posterior chamber IOLs with capsular tension ring (CTR), and scleral-fixated IOLs can be implanted, but with longer duration of surgery, higher risk of corneal endothelial cell loss, glaucoma, dislocated IOL and CTR, and retinal detachment.

The Artisan IOL (iris claw) is one of the best options and a good alternative for 
inadequate capsular support as it has a good visual outcome, shorter duration of surgery, and lower incidence of intra- and postoperative complications than other types of IOL. It was designed to avoid direct contact with the iris (except at the clamping site), which reduces the risk of iris trauma and inflammation.

Sarioglu et al. reported a case where they implanted double Artisan IOL (anterior and posterior) and three years follow up showed preserved corneal endothelial cells, normal intraocular pressure and good visual outcome. ${ }^{9}$ Lifshitz et al. successfully implanted the Artisan IOL in four paediatric eyes with good visual outcome and without any complications. ${ }^{10}$

Another main advantage of the Artisan IOL is it can be unclipped from the iris with a simple, relatively atraumatic motion and exchanged for a new IOL of appropriate power. It offers a less traumatic IOL exchange procedure as the child grows and refraction changes.

Thus, for this patient, we successfully performed early lens extraction to prevent amblyopia and allow early visual rehabilitation. We chose the Artisan IOL due to its advantages, as outlined above.

\section{Conclusion}

Ophthalmologists play an important role in diagnosing MS. Early surgical intervention is highly recommended in paediatric patients with lens dislocation and subluxation to prevent amblyopia.

The Artisan IOL is a safe and effective means for early visual rehabilitation with less complications compared to other IOLs. It is also technically much easier to replace if IOL exchange is needed due to changes in the patient's refraction.

\section{Acknowledgements}

The authors would like to thank the Director General of Health Malaysia for the permission to publish this paper.

\section{References}

1. Boileau C, Jondeau G, Mizuguchi T, Matsumoto N. Molecular genetics of Marfan syndrome. Curr Opin Cardiol. 2005;20(3):194-200.

2. Gehle P, Goergen B, Pilger D, Ruokonen P, Robinson PN, Salchow DJ. Biometric and structural ocular manifestations of Marfan syndrome. PLoS One. 2017;12(9):e0183370. 
3. Romano PE, Kerr NC, Hope GM. Bilateral ametropic functional amblyopia in genetic ectopia lentis: its relation to the amount of subluxation, an indicator for early surgical management. Binocul Vis Strabismus Q. 2002;17(3):235-241.

4. Eapen V, Črnčec R, Walter A. Clinical outcomes of an early intervention program for preschool children with Autism Spectrum Disorder in a community group setting. BMC Pediatrics. 2013;13(1):3.

5. Strider D, Moore T, Guarini J, Fallin B, Ivey J, Kron I. Marfan's syndrome: a family affair. J Vasc Nurs. 1996;14(4):91-98.

6. Maumenee IH. The eye in the Marfan syndrome. Trans Am Ophthalmol Soc. 1981;79:684-733.

7. 2010 revised Ghent nosology. Available from: https://www.marfan.org/dx/revised-ghent-nosology.

8. Kanigowska K, Gralek M, Klimczak-Slaczka D. [The estimation of functional results after surgical treatment for ectopia lentis in children]. Klin Oczna. 2005;107(7-9):460-463.

9. Sarioglu FAO, Tasci YY, Kurtul BE, Boluk SO. Implantation of a double iris-claw intraocular lens in an aphakic nanophthalmic eye. Indian J Ophthalmol. 2017;65(12):1490-1492.

10. Lifshitz T, Levy J, Klemperer I. Artisan aphakic intraocular lens in children with subluxated crystalline lenses. J Cataract Refract Surg. 2004;30(9):1977-1981. 